\title{
Portuguese Pronouns and Other Forms of Address, from the Past into the Future- Structural, Semantic and Pragmatic Reflections
}

\author{
Manuela Cook \\ University of Wolverhampton
}

\begin{abstract}
This paper examines the Portuguese second-person system and forms of address as they stand today, at the beginning of the twenty-first century. It considers both their roots and significant stages of evolution and how both are shaping the current situation. It also cogitates about possible further changes. These reflections will use the $\mathrm{N}-\mathrm{V}-\mathrm{T}$ framework of analysis (Cook, "Uma Teoria"), deemed to be better suited than the V/T duality (Brown and Gilman).
\end{abstract}

Keywords: Portuguese language, second person, form of address, formal/informal, neutrality, tu, você, o senhor / a senhora, power and solidarity.

The Portuguese language inherited from the Latin two second-person pronoun and verb paradigms. These served the sociolinguistic requirements of the time. However, along the centuries, changes have inevitably occurred in the way interpersonal and intergroup relations are understood and promoted through pronouns and other forms of address. Accordingly, structural and semantic innovation has taken place.

This paper seeks to accomplish two specific objectives: to visit the Portuguese second-person system in its overall composition and debate the interpretation of current structural and semantic trends. It takes a diachronic and synchronic view. Historically, it discusses a decisive step of far-reaching consequences concerning morphosyntactic evolution and highlights a new orientation concerning mode of address. In respect of today's practice, it ponders the 
current status quo in the Lusophone world and speculates about the future. Geographical variation is taken into account where it plays a significant role. Additionally, as an extra thread of discussion, comparisons will be made between Portuguese and English performance.

The Portuguese second-person system will be initially discussed within the customary formal/informal V/T binary of assessment based on Brown and Gilman's study of pronouns of address. Subsequently Cook's N-V-T framework of analysis ("Uma Teoria") will be called upon as a more comprehensive theoretical model that will enable a clearer understanding of the Portuguese second-person system and forms of address. The examples quoted in the discussion represent acknowledged practice as confirmed by previous academic research and as registered in descriptive and normative grammar texts.

\section{The Portuguese second-person subject: origin and evolution}

In today's world of Internet facilities and prompt global communication, the English language is the main lingua franca, as acknowledged by many, for instance Crystal (English as a Global Language; Language and the Internet). It is understandable that other idioms may feel pressure to bring some of their features closer to English so as to become more accessible to Anglophone speakers.

For an Anglophone speaker, "você" is a convenient encoder for English "you" as a gateway into the Portuguese second-person system. However, a deeper understanding is required for a proficient grasp of grammatical, semantic and pragmatic subtleties. An introductory step in that direction is taken in the first section of the present paper, which looks at the subject constituent for the second person in the Portuguese language throughout the times, from its earliest forms to the key elements in current practice.

\subsection{The Latin inheritance}

Originally, as received from Latin, the Portuguese second person had two distinct subject pronouns, "tu" (Latin $t \overline{\mathrm{u}}$ ), when addressing one individual, and "vós" (Latin $v \bar{s} s$ ), for more than one. To these subject pronouns corresponded distinctive endings in the accompanying verbs. In addition to denoting plural, subject pronoun "vós", with its accompanying verb ending, also served another 
function. It was the form of address for individuals of high standing. (MattosoCâmara 76-8, 121-8; Silva-Neto 234-48; Teyssier 29; Azevedo 272).

E.g., Tu falas, You speak (addressing one individual) Vós falais, You speak (addressing more than one individual) Vós falais com sabedoria, You speak wisely (addressing for example the king)

In this initial second-person system in the Portuguese language there were, therefore, two subject constituents, "tu" and "vós", the former for informal address and the latter both for plural and a formal approach. In both cases, there was a double second-person marker, subject pronoun (tu, vós) and verbal inflection (-as, -ais (in the quoted examples)).

\subsection{Period of transition}

Later on, from the fourteenth century, came the practice of addressing people of high standing by eulogistic reference to their most acknowledged attribute. This model corresponded to a new trend in several parts of Europe and had its roots equally in Latin, where the emperor used to be addressed as "Uestra Maiestas" (Your Majesty). In Portugal, "Vossa Mercê" (Your Mercy) became an established form of addressing the monarch. (Lindley-Cintra 18-23; MattosoCâmara 80-81).

The subject constituent was typically a phrase consisting of an abstract noun (e.g., Mercê, Mercy) preceded by a possessive (Vossa, Your). The noun component attracted the third person singular of the verb.

\section{E.g., Vossa Mercê fala com sabedoria, Your Mercy, you speak wisely, literally, Your Mercy speaks wisely}

The shift in verb ending-from second-person plural to third-person singular-underwent a period of transition. This phase of adaptation is well documented in the 1453 "Crónica dos Feitos da Guiné," by Portuguese chronicler Azurara. When dedicating his work to the king of Portugal, he writes the 
following: “... stando Vossa Mercee o anno passado em esta cidade, me dissestes ..." (when staying in this town last year, Your Mercy (= you) told me) (ii). Here a nominal subject (Vossa Mercee) is used jointly with the traditional verb ending for the second person plural (dissestes). Over time, paradigmatic agreement was attained; and third-person verbal inflection became the norm for a nominal subject.

\subsection{A new format}

Once for the monarch, "Vossa Mercê" was later used more widely for different members of the aristocracy and clergy and subsequently also members of the bourgeoisie. As it came down the social scale and lost its previous glamour, it also suffered various phonetic alterations and reductions; and eventually became "você", with plural "vocês". (Lindley-Cintra 25-36; Cook, "On the Portuguese Forms of Address"; Teyssier 59-60).

"Você", you, is for addressing one person, and "vocês" for more than one person (Moura-Neves 458; Bechara 165). Not unlike a noun, this noun-based word takes plural ending -s.

\section{E.g., Você fala, You speak (addressing one individual) \\ Vocês falam, You speak (addressing more than one individual)}

Both the subject constituent and the accompanying verb endings are distinctive between singular and plural. However, these verb endings are shared with the third person-"você fala", you speak, or "ele/ela fala", he/she speaks, and "vocês falam", you (more than one) speak, or "eles/elas falam", they speak (Perini 258-9; Moura-Neves 458). The subject word can be called upon as a disambiguating marker.

Its noun etymology lost in the mist of time, "você", with plural "vocês", came to serve as a subject signifier for an informal approach. Nouns, with their identifying and classifying properties, continued to provide for a formal alternative. Masculine and feminine nouns, "senhor", sir (i.e., gentleman) and "senhora", madam/ma'am (i.e., lady) and their respective plurals, "senhores" and "senhoras", came to be the main choice to fulfil a polite function on a general 
basis. (Vázquez-Cuesta and Mendes da Luz 482-92; Moura-Neves 450, 458; Azevedo 265-75; Bechara 165)

E.g., O senhor fala Inglês?, Do you speak English, sir? (addressing a stranger) (more literally, Does the gentleman speak English?)

Os senhores falam Inglês?, Do you speak English, sirs? (addressing strangers)

(more literally, Do the gentlemen speak English?)

(Please note that masculine plural 'os senhores' may also include both genders.)

\subsection{Current practice}

The above diachronic tour may suggest that the original "tu-vós" system has been replaced with the more recent "você-o senhor / a senhora" system and respective plural forms. It is not entirely so, as discussed below.

The discussion will focus on the common ground available synchronically across the Portuguese-speaking world. Geographical variation is included where it provides a key contribution.

I am going to use the terms tu-paradigm and vós-paradigm meaning verbal inflection, object pronouns and possessives related to respectively the "tu" and "vós" subject pronouns, independently of this element being expressed or not. The term nominal-format will refer to third-person verbal inflection and will encompass noun-based "você", nouns "senhor / senhora" and any other nominal expression used as a subject marker, both singular and plural.

In the informal sphere, the nominal-format for "você" is joined by tu-paradigm elements for a more familiar, matey or intimate approach. Practice varies between Portugal and Brazil, an aspect which will be discussed later in this paper. Although there are two options for informality when addressing one individual, both merge into one single option when relating to more than one person-pluralized "você" and third-person plural verb ending-Vocês falam, You speak. In the formal sphere, the general practice for politeness is the nominal-format with subject marker "o(s) senhor(es) / a(s) senhora(s)". (Moura-Neves 458; ThoméWilliams; Azevedo 265-75; Bechara 164-5; Tostevin and Cook; Barros 160-67) 


\begin{tabular}{lll}
\hline SINGULAR & PLURAL & TONE \\
\hline tu & vocês & informal \\
você & & \\
\hline o senhor / a senhora & os senhores / as senhoras & formal \\
\hline
\end{tabular}

While subject pronoun "tu" can still be heard, the same can hardly be said for subject pronoun "vós", which you may not hear at all or only in special registers, such as liturgy (Moura-Neves 461-3; Azevedo 265-75). In general practice, as a plural form, "vós" has been replaced with "vocês" (informal) and "os senhores / as senhoras" (formal) (Moura-Neves 458; Azevedo 265-75; Bechara 165-6).

Summing up, in modern Portuguese, the nominal format has taken the lead in second person provision - with a noun (o senhor / a senhora) or nounbased (você) subject and a third-person verb ending-but the "tu" approach is still quite active. This is a common denominator across the Portuguese-speaking world. We shall discuss geographical variation, west and east of the Atlantic Ocean, as relevant. Some diversity can be found within Brazil itself, a country of continental proportions and many states (Azevedo 211-14). Norms preferred in Portugal tend to be equally the preference in Portuguese-speaking countries and other areas in Africa and Asia (Azevedo 21), which reflects the historical fact that their independence from Portugal, after 1974, is relatively much more recent than that from Brazil, in 1825.

\section{Today's Portuguese second-person system: the wider picture}

We have looked at the current situation in respect of second-person subject constituents and accompanying verbal inflection. We shall now consider the second person in other grammatical categories, namely the oblique pronouns and the possessives.

As done in 1.4 in respect of subject constituents, the focus will continue to be on the core material available synchronically across the Portuguese-speaking world. Geographically this common core will be open to local diversification.

Across this spectrum-oblique pronouns and the possessives-two main aspects are considerably meaningful. One is that the nominal-format has 
attracted the practice of third-person grammatical forms; and potential ambiguity can be resolved by pragmatic or semantic means. The other is the fact that elements from lexeme "tu" and lexeme "vós" are being used for a specific meaning and/or disambiguation, the same applying to their respective possessives.

\subsection{Object pronouns}

The third-person direct object personal pronouns are the following morphemes: o (him/it), a (her/it), os (them, masculine and neuter), as (them, feminine and neuter). When they are borrowed for the second person, their assigned meaning becomes the following: o (you, masculine), a (you, feminine), os (you, masculine plural), as (you, feminine plural). Where situational context does not resolve potential ambiguity, a first line solution is the reiteration of the nominal subject word(s).

E.g., Quando eu vi você, When I saw you (informal, addressing a male or female)

Quando eu vi os senhores, When I saw you (formal, addressing males, or male and female)

(Please note that masculine plural 'os' (pronoun) and 'os senhores' can comprise both genders.)

The tu-paradigm contributes morpheme "te", which is not needed for disambiguation but imparts a familiar tone.

E.g., Quando eu te vi, When I saw you (informal [familiar], addressing a male or female)

For the plural, an alternative option is morpheme "vos", a pronominal form out of the vós-paradigm.

E.g., Quando eu vos vi, When I saw you (informal or formal, addressing males or females) 
The third-person indirect object personal pronouns are the following morphemes: lhe (to, for him/her/it), and lhes (to, for them, masculine, feminine and neuter). When they are borrowed for the second person, their assigned meaning becomes the following: lhe (to, for you, masculine and feminine) and lhes (to, for you, masculine and feminine plural). Similarly to the direct object, ambiguity can be overcome by the reiteration of the nominal subject word(s).

E.g., Quando eu comprei um presente para você, When I bought a present for you (informal, addressing a male or female) Quando eu comprei um presente para as senhoras, When I bought a present for you, ladies (formal, addressing females)

For an indirect object, the tu-paradigm contributes both morpheme "te" and its strong form "ti". These are used to impart a familiar tone.

E.g., Quando eu te comprei um presente, When I bought you a present or

Quando eu comprei um presente para ti, When I bought a present for you (informal [familiar], addressing a male or female)

For the plural, an alternative option is a morpheme out of the vós-paradigm, either "vos" or its strong form "vós", which is identical to the subject pronoun and seldom heard.

E.g., Quando eu vos comprei um presente, When I bought you a present or Quando eu comprei um presente para vós, When I bought a present for you (informal or formal, addressing males or females)

As for the second-person object preceded by preposition, we have seen the construction where the object can be a reiteration of the word(s) in the nominal subject-e.g., para as senhoras-or an oblique pronoun-e.g., para ti. 
In the particular case of preposition "com" (with) contraction takes place with the pronoun: "contigo" (with you, singular), and "convosco" (with you, plural).

E.g., Eu vou com você, I am going with you

(informal, addressing a male or female)

Eu vou com as senhoras, I am going with you, ladies

(formal, addressing females)

but

Eu vou contigo, I am going with you

(informal [familiar], addressing a male or female)

Eu vou convosco, I am going with you

(informal or formal, addressing males or females)

Finally, distinct from formal "o senhor / a senhora" and adjacent to informal "você", there is also third person singular "si", $\operatorname{him}($ self $) / \operatorname{her}($ self), and respective contracted forms.

E.g., Eu comprei um presente para si, I bought a present for you Eu vou consigo, I am going with you

(void of a familiar tone though informal, addressing a male or female)

Further detail and more examples can be found for instance in Azeredo 122; Perini 98-9; Moura-Neves 451-70; Bechara 164-76; and Barros 160-67.

\subsection{Possessives}

The third-person possessives, "seu/sua" (his/her(s)/its), agree in gender and number with the possessed item-e.g., seu carro (masculine) (his/her car), sua casa (feminine) (his/her house); seus carros (his/her cars), suas casas (his/her houses). Yet again, in this grammatical category the third person is used for the second. Thus, borrowed from the third person, "seu/sua" are used for your(s). Nominal forms are also available.

E.g., Este é o seu carro, This is your car (informal, addressing a male or female) 
Estas são as chaves das senhoras, These are your keys, ladies (formal, addressing females)

Although "seu/sua, seus/suas" can relate both to a singular and a plural subject, for increased clarity a plural form is available from the vós-paradigm, possessive "vosso/vossa, vossos/vossas". It can be used both informally and formally, but nowadays the latter function tends to be served by "senhores/as".

E.g., Este é o vosso carro, this is your car

(informal or formal, addressing more than one male or female) Este é o carro das senhoras, this is your car, ladies (formal, addressing females)

The tu-paradigm contributes the possessive for a familiar tone: "teu/tua, teus/tuas".

E.g., Este é o teu carro, This is your car (informal [familiar], addressing a male or female)

In the above quotes the possessives are used adjectively-your. The situation is identical for pronoun use-yours.

E.g., Este carro é teu, This car is yours (informal [familiar], addressing male or female)

Este carro é vosso, This car is yours (informal or formal, addressing males or females)

Further detail and more examples can be found for instance in Azeredo 122-3; Perini 304-6, 339-40; Moura-Neves 472-89; Bechara 166-187; and Barros $169-70,178-9$.

As announced at the beginning, this section seeks to highlight a pool, a common supply, available for sharing across the Lusophone world. Out of this 
melting pot, elements will be chosen according to preferences associated with geographical location, socio-cultural background and register.

Attention has been drawn to a phenomenon of paradigmatic analogy where the nominal-format has led to the adoption of third-person grammatical forms for object pronouns and possessives. Another matter worth noting is the nominal-format's supply of alternatives for disambiguation or more precise semantic content, with informal "você" and formal "o senhor / a senhora". However, both the vós- and the tu-paradigms equally make their input, for disambiguation or more precise semantic meaning, the former modestly and the latter with a more lively performance. As compared to what was observed in section 1 for the second-person subject, in respect of object and possessive markers, two routes co-exist, one of a nominal nature, the other pronominal. In the latter, elements of the old vós- and tu-paradigms are at work.

3. The social dimension in the Portuguese second-person system today

In this paper, the Portuguese second-person system has been so far discussed within a binary formal/informal classification, which has been the customary avenue (Azevedo 265-75). This scheme of evaluation, however, does not cover all the relevant facets. We have already come across two different choices within the informal sphere, "você" and "tu". There are also other aspects that lie outside the remit of a formal/informal duality. In the present section we shall move on to a more comprehensive scheme of evaluation, with which we shall examine the Portuguese second-person system.

\section{$3.1 \mathrm{~V} / \mathrm{T}$ or $\mathrm{N}-\mathrm{V}-\mathrm{T}$ ?}

The generalized formal/informal classification for second-person systems is based on a theoretical framework of analysis put forward by Brown and Gilman in the second half of last century (1960). According to these authors, the way people relate to each other is determined by two vectors, power and solidarity, as a result of which there are two distinct approaches they termed $\mathrm{V}$ and $\mathrm{T}$ after Latin $v \bar{o} s$ and tū. In interaction based on solidarity, reciprocal V or T would be used. In power-driven interaction, the dominant addresser would use 
T but receive V. Brown and Gilman showed awareness that, in modern societies, display of power may not be accepted as politically correct. However, no means of assessment were provided beyond a V/T duality.

The main embarrassment in the $\mathrm{V} / \mathrm{T}$ theory when applied to modern societies is failing to consider a stage of neutrality. Seeking to fill this gap, Cook ("Uma Teoria"; "Portuguese forms of address") has proposed a revised framework of analysis, substantiated with a direct application to the Portuguese language. Cook's N-V-T takes neutrality, $\mathrm{N}$, as a noncommittal platform, while still considering $\mathrm{V}$ and $\mathrm{T}$ shades of formality or informality. The Latin symbols $\mathrm{V}$ and $\mathrm{T}$ remain, though attuned to sociolinguistic evolution, as they are befitting reminders of the nonreciprocal interaction which may be expected in a number of hierarchical contexts, e.g., the military, and may also occur, openly or covertly, in society in general.

The favoured display of solidarity in modern societies requires a changed $\mathrm{V} / \mathrm{T}$ perspective. These symbols may no longer stand for a power-driven stance and a vertically asymmetrical relation, i.e., one of dominance-subservience between superior and inferior. Instead, they may be expected to convey a samelevel relation, i.e., a horizontal widening or narrowing of social space in relation to the addressee. Distance will be appropriate between strangers; closeness will be reserved for those sharing affinity on the grounds of kinship, friendship or membership of the same professional or recreational association. V/T dynamics can be negotiated from platform $\mathrm{N}$.

Brown and Gilman's treatment of forms of address concentrates on the vertical axis of social class, and Cook's proposal ("Uma Teoria") brings in the horizontal. Parallels to these two viewpoints can be detected in other areas of sociolinguistics, namely, the former in Labov (I, II), the latter in Bell and Coupland. While the traditional vertical axis will not lose its relevance, it has become insufficient to assess language in society today. The horizontal plane has become an essential consideration. In section 1.4 of this paper we looked at the three key address markers in current practice across the Lusophone world, namely "tu", "você," and "o senhor / a senhora". In the following sections these will be discussed within the N-V-T framework of analysis. 


\subsection{Achieving N-V-T in Portuguese}

As we have seen, Portuguese has fundamentally three address approaches, formal "o senhor / a senhora" and, outside the formal sphere, both "você" and "tu". We shall next analyze these three approaches, from both a grammatical and sociolinguistic angle, and examine how they articulate in the N-V-T triad.

\subsubsection{Achieving $\mathrm{N}$}

Subject constituent "você" is a potentially suitable N encoder (Cook "Uma Teoria", "Portuguese Forms of Address"). The noun in its origin lost in phonetic change, it may be perceived by most speakers as a pronoun, which may facilitate its performance as a semantically uncommitted subject unit-e.g., 'Você fala Inglês?', Do you speak English?. On the other hand, there is an ambivalence to be considered and a distinction to be made between east and west of the Atlantic.

A nominal subject-word has a characterizing effect when it consists of a noun with an identifying or classifying function in the language. As a phonetically compressed nominal expression of by-gone times, "você" no longer carries any such explicit content, but, in Portugal, this semantic void gave place to a default meaning. By contrast with polite V "o senhor / a senhora", it became the subject word for someone felt not to merit a complimentary form of address. However, its status has been improving for decades (Cook, "'You' the customer"; Azevedo 265-75), bringing it more in line with the practice on the other side of the Atlantic. In Brazil, "você" stands equally in contrast with polite V "o senhor / a senhora" but has since long enjoyed a more positive existence (Moura-Neves 458, 472; Azevedo 265-75; Bechara 165).

Although with "você" third-person elements are used for the second person, disambiguation may not always be necessary. For example in face-to-face interaction, it should be obvious the second person is meant, not the third, in a question such as "Fala Inglês?", Do you speak English?. Therefore, where clear information is achieved pragmatically, the subject word(s) can be safely dispensed with, for grammatical simplification. Withholding the subject marker may also be turned into a strategy for achievement or enhancement of a neutral approach-the signifier is absent, it is a zero subject. This is a practice heard 
on both sides of the Atlantic, but more persistently on the eastern side (Cook “Uma Teoria”, Perini 268; Thomé-Williams; Azevedo 265-75; Barbosa et al.).

\subsubsection{Achieving $\mathrm{T}$}

In the tu-paradigm, a distinctive verb ending enables the subject word to be dropped without the potential loss of the intended meaning-e.g., "Tu falas Inglês?", Do you speak English?, or “Falas Inglês?", Do you speak English?. Omission of subject pronoun "tu" may occur as a mere grammatical simplification; its inclusion may be explored for semantic emphasis though not necessarily so. Both are heard.

In Portugal, the tu-paradigm - with subject word "tu" expressed or omitted-is the approach where a tone of intimacy is to be imparted, with close family members and friends and with children, as well as for camaraderie. In Brazil, elements of the tu-paradigm are also used, but in most states, "você" subject word and its nominal-format cover the area of close family members and friends as well as that of children. However, tu-paradigm oblique pronouns (te, ti) and possessives (teu/tua, teus/tuas) are often used in conjunction with "você" (Moura-Neves 458, 472; Azevedo 265-75; Scherre et al.), so as to impart a tone of camaraderie, or intimacy-e.g., "Você estava no aeroporto? Eu não te vi lá.", Were you at the airport? I didn't see you there. With assistance from devices of this nature, from its relative $\mathrm{N}$ position, "você" reaches out into the T zone.

There is a thought-provoking situation in Brazil. This is the case mainly in the southern and the north-eastern states, as well as in coastal São Paulo and in parts of Rio de Janeiro. In these areas the "tu" subject constituent is the choice but not always with its respective verbal inflection. Particularly on the north-eastern coast, this distinctive verb ending may be felt as the odd one out, and a solution has been sought, i.e., uniformity with the "você" and "o senhor / a senhora" inflection. A shift has taken place in that second-person pronoun "tu" is conjugated with the third-person verb ending, i.e., "Tu fala", You speak (Cook, "Portuguese Verbs" 17; Thomé-Williams; Azevedo 265-75). In this development, subject word "tu" cannot be dispensed with, as it is the only subject marker for one single verb ending shared by the N-V-T triad: você fala (N); tu fala (T); o senhora / a senhora fala (V). 


\subsubsection{Achieving V}

Structurally, a V effect is obtained with the nominal-format. Semantically, the noun element in the subject constituent provides the intended identifying and classifying properties, in varying degrees of formality.

Politeness is generally conveyed via subject nouns "senhor/senhora" and their respective plurals. As common nouns, they stand for gentleman and lady. In their capacity as forms of address, the closest English rendering is sir and madam. There are also very formal V expressions. For example, "Vossa Excelência" (Your Excellency) is used when addressing a head of state, "Vossa Majestade" (Your Majesty) for royalty, "Vossa Eminência" (Your Eminence) for ecclesiastic dignitaries. These are obviously reserved for a ceremonial context (Perini 258-9; Moura-Neves 458, 472; Thomé-Williams; Azevedo 265-75; Bechara 165-6, 186).

\begin{tabular}{lll}
\hline SINGULAR & PLURAL & TONE \\
\hline tu & vocês & $\mathrm{T}$ \\
você + te, etc. & & \\
\hline você & vocês & $\mathrm{N}$ \\
\hline o senhor / a senhora & os senhores / as senhoras & $\mathrm{V}$ \\
\hline
\end{tabular}

Summing up, the N-V-T evaluation of the three key address approaches in Portuguese reveals each one's basic role. For $\mathrm{V}$, a noun-subject constituent is firmly in place, west and east of the Atlantic Ocean. For N, there is slight variation of practice. For T, variation of practice is noteworthy.

In Brazil, the nominal-format with subject constituent "você" is the predominant choice. For a tone of familiarity, matiness or intimacy, the tu-paradigm is partially used through the oblique elements of lexeme "tu" and its respective possessives. Subject constituent "você" occupies thus position $\mathrm{N}$ in the $\mathrm{N}-\mathrm{V}-\mathrm{T}$ triad though also reaching into $\mathrm{T}$. The $\mathrm{V}$ approach is served by the nominal-format with "o senhor / a senhora" as its main subject constituent.

In Portugal, position $\mathrm{N}$ in the $\mathrm{N}-\mathrm{V}-\mathrm{T}$ triad is occupied predominantly by the nominal-format with omission of the subject constituent, i.e., for example 
"fala" for "você fala" (you speak). For a familiar, matey or intimate approach, the whole range of the tu-paradigm is the choice, with subject constituent "tu" either expressed or omitted. The $\mathrm{V}$ approach is served by the nominal-format with "o senhor / a senhora" as its main subject constituent.

\subsection{Portuguese N-V-T dynamics}

"Once an originally third-person form is adopted for second person reference, a language has access to a very open system of second person reference, far beyond the closed system of the personal pronouns" (Pountain 150). This is very true in the case of Portuguese.

We have seen how N, V and T are achieved in Portuguese and how the nominal-format stands out as the main second person provider. We shall now focus on N-V-T dynamics resulting from the use of a variety of subject markers.

The nominal format is a source of multiple opportunities. Thanks to its noun content, the subject constituent can be substituted and/or extended in order to provide information for several purposes, for instance, situational definition. This applies not only in one-to-one communication but also when addressing a group-e.g., Os senhores passageiros devem aguardar na sala de espera. Passengers are requested to wait in the waiting room, more literally, You, sir and madam passengers, should wait in the waiting room. In dyadic interaction, semantic extension may also include occupational attribution-e.g., a senhora professora (teacher); and academic or rank status-e.g., a senhora Doutora (Doctor), o senhor Ministro (Minister). Whether or not a V subject constituent is chosen may depend on social circumstances. For example, in employment, an individual who is normally addressed in $\mathrm{N}$ or $\mathrm{T}$ by the other company members may be addressed in $\mathrm{V}$ when chairing a meeting- $\mathrm{o}$ senhor presidente (chairman).

Age may influence N-V-T demarcation. A schoolteacher may expect to be addressed in $\mathrm{V}$ by his/her pupils-o senhor professor / a senhora professor (teacher) -, but this requirement decreases as the children grow towards adulthood. At university level it may be left only to circumstances such as an examination. Outside the realms of contextual formality, there are different selections too. Child-adult interaction may occur in T, but older generations may prefer to be addressed another way. In Brazil, some senior family members and 
acquaintances may expect to receive $\mathrm{V}-\mathrm{o}$ senhor / a senhora. In Portugal some senior family members may expect to be named after their respective relationship-e.g., O pai acha que isto está bem?, Does father think this is all right?, or, more freely translated, Do you think this is all right, father/dad?. Rather than $\mathrm{V}$, this can be classed as N-V. As for adult family acquaintances, $\mathrm{V}$ is a possibility-o senhor / a senhora -, but the individual's first name can also be used. This technique is explained in the next paragraph.

Within the V sphere, the combined use of "senhor(a)" and the addressee's name can be manipulated for degree of formality. It will be more formal when used with a surname- "o senhor Oliveira" -, but not so much so with a first name-"o senhor David", which can twin with feminine "a dona Maria" (an abridgement from 'senhora dona'). As a further step down, moving from $\mathrm{V}$ to $\mathrm{N}$, a popular practice in Portugal is to address an acquaintance by his/her first name-e.g., "a Rita"-which confers a personal touch to a possible zerosubject $\mathrm{N}$ approach without actually entering the T sphere.-e.g., A Rita fala Inglês?, Do you, Rita, speak English? (literally, Does Rita speak English?).

Concerning the top levels of the V sphere, special mention is due to the very formal "Vossa Excelência", Your Excellency (reminiscent of Renaissance honorifics in its composition, with possessive "vossa") which is used in dyadic interaction when addressing e.g. A head of state. Curiously, its vertical nonreciprocal movement is reversed in a horizontal counterpart, as a form of address directed by Officialdom to the ordinary citizen in written correspondence, notably in Portugal. However, the best example of N-V-T mobility may come from west of the Atlantic. A popular practice in Brazil is to use "seu" instead of "o senhor"-e.g., "seu David"-thus stepping out of the V sphere. This approach hovers between the $\mathrm{N}$ and $\mathrm{T}$ spheres due to its overtones of matiness and the light-hearted connotations it carries as a result of possessive "seu/ sua" (your) being used idiomatically with the noun-e.g., Seu David quer um cafezinho?, You, David, would you like a cup of coffee?. It is the same linguistic strategy as used for a variety of epithets, some more complimentary than others-e.g., Seu janota!, You, dandy!.

As illustrated above, a third-for-second-person adoption has given the Portuguese language a very open system of second person reference that 
enables a creative N-V-T continuum. This quality is a notable advantage bearing in mind the worldwide spread of the Portuguese language. As official language, and also in other capacities, Portuguese is spoken virtually on every continent. Taking a circumnavigation of the globe, amongst others, the following locations can be quoted: Brazil, Azores, Madeira, mainland Portugal, Cape Verde, Guinea-Bissau, Equatorial Guinea, Sao Tome and Principe, Angola, Mozambique, Macau, East Timor. By a mere substitution of subject word(s), adjustments can be easily made to cater for sociolinguistic requirements around the Lusophone world.

\section{The Portuguese second-person system: today and tomorrow}

The structural dominance and versatility of the nominal-format has not gone unnoticed to observers; nor has the fact that this situation may endanger the original tu- and vós-paradigms. Pountain comments on the development of "third-as-second person forms" in Portuguese and "how this is a structural possibility on which Portuguese builds." To this he adds: "In the same way, we might speculatively suggest that the richness of this possibility militates against the survival of the original pronominal forms" (159). This is a complex issue.

Indeed, as explained in section 1 of this paper, on both sides of the Atlantic at large, subject pronoun "vós" is no longer in general use either as a plural or a $\mathrm{V}$ encoder; and the same applies to its corresponding verbal inflection. It has been replaced with "vocês" (N, T) and "o(s) senhor(es) / a(s) senhora(s)" (V). With regard to $\mathrm{T}$, as explained in section 1 , and further examined in section 3, subject pronoun "tu" enjoys a healthy existence east of the Atlantic; and so does its corresponding verbal inflection. West of the Atlantic, "tu" may appear to have been dislodged by subject word "você" and its corresponding thirdperson verb ending. It is interesting that in colloquial speech in Brazil, "você" is often phonetically reduced to "cê" (Perini 101; Thomé-Williams; Azevedo 272; Gonçalves). This is a monosyllable, like "tu", perhaps a sign that it is felt to be a convenient replacement. Or perhaps it is destined to be an alternative.

In fact, although in Brazil "você" may appear to have replaced "tu", the tu-paradigm is alive and very much so. Its most concealed, though pervasive, involvement may be in the form of verbal inflection shared between second 
and third persons. The tu-paradigm verb ending for the Imperative Mood coincides with the nominal-format third person singular Indicative Mood, Present Tense (Cook, "Portuguese Verbs" 16-18, 193; Borges-Cardoso 108-9). Therefore, "Olha!" (Look!) is the tu-paradigm Imperative, and "(Você) olha" is the "você" nominal-format Present Indicative. An instruction can be given in either way. In "Toma a primeira rua à direita" (Take the first road on your right), the addressee is being related to in $\mathrm{T}$ (tu-paradigm Imperative); and s/he receives a command. In "(Você) toma a primeira rua à direita" (You take the first road on your right), the addressee is being related to in $\mathrm{N}$ ("você" subject marker, expressed or omitted, plus nominal-format Present Indicative); and s/he receives a description of the required action. The verb ending, -a, is the same. This mixed verbal inflection may not be obvious to many speakers. Furthermore, it may be receiving reinforcement from the practice of conjugating "tu" subject word with third-person verb ending, a phenomenon with a significant geographical spread in Brazil, and which was discussed in section 3 of the present paper.

The conjoining of second-person pronoun "tu" with the third-person verb conjugation-e.g., Tu fala, You speak-is a phenomenon coming from the vernacular, what Labov would class as a "change from below" (I and II). It may shock many as being rather ungrammatical; and it would require an adjustment on the eastern side of the Atlantic: tu falas $\rightarrow$ tu fala. However, if it were to receive ratification from above, it would result in an extension to the singular of what is already established for the plural, where the different $\mathrm{N}-\mathrm{V}$-T subject constituents share the same verb ending-e.g., Vocês falam, You speak ( $\mathrm{N}$ and T), Os senhores / as senhoras falam, You speak (V). If this shift were to materialize into standard practice, one could say that subject pronoun "tu" would have a future, not as such, but reborn as a subject marker in the nominal-format, on a par with "você" and "o senhor / a senhora".

Subject word "você" was introduced in section 1 and analyzed in section 3. This unit may be an excellent candidate for an uncommitted position of neutrality in the Portuguese N-V-T triad, comparable to the all-encompassing English you. To this effect, in Brazil, the "você" subject constituent would benefit from the above-mentioned shift, as it could thus be released from its close-relations link and undertake a well-defined N function. In Portugal, 
"você" appears to be successfully shedding its former negative overtones, which will enable it to equally occupy a well-defined $\mathrm{N}$ position. In either case, as a backup, a zero subject can always provide unquestionable neutrality.

\begin{tabular}{lll}
\hline SINGULAR & PLURAL & TONE \\
\hline tu & vocês & T \\
\hline você & vocês & $\mathrm{N}$ \\
\hline o senhor / a senhora & os senhores / as senhoras & $\mathrm{V}$ \\
\hline
\end{tabular}

In today's English, while $\mathrm{N}$ is provided grammatically, with uncommitted you, $\mathrm{V}$ and $\mathrm{T}$ are provided semantically via nouns and tend to be expressed vocatively. This nominal alternative is a means of compensating for the lack of a T/V pronominal distinction (Clyne et al. 17-18). In the family circle, a father will likely address his son as John, or Johnny, but he may expect the child to address him as Dad. In society at large, the general V form is "sir/madam", described in the Concise Oxford Dictionary as a "polite or respectful form of address or mode of reference" to a man/woman. For $\mathrm{T}$ there is a long list which includes, amongst others, "mate, dear, honey, babe" (Brown and Levinson 107-8). $\mathrm{V}$ and $\mathrm{T}$ forms are, therefore, outside elements that are brought in and added on where the $\mathrm{N}$ approach falls short of the intended sociolinguistic effect. In Portuguese, a vocative apposition is not needed for $\mathrm{V}$ or $\mathrm{T}$, because morphological and syntactic provision is available for these effects-e.g., "Isto é para o senhor", This is for you, sir; and "Isto é para ti", This is for you, dear. The English apposition for $\mathrm{V}$ and $\mathrm{T}$ is more frontal and yields a sharper contrast. This may explain why Portuguese "o senhor / a senhora" appears to sound rather formal to Anglophone ears. The available translation-sir and madam, respectively - may suggest a higher grade of $\mathrm{V}$ content than it actually carries.

Finally, let's look beyond subject markers and revisit the contents of section 2, where we examined provision for second-person oblique forms and possessives. It was observed that elements are in use both out of the vós-paradigm - such as "vos", "convosco", "vosso"-and, much more so, out of the tuparadigm-such as "te", "contigo", "teu". Equally at work are forms that echo 
the subject word(s), for instance, "você", resembling the English dual role for you-você fala, you speak (subject); eu vi você, I saw you (object). Except for the obliques of the tu-paradigm, there is a split between two practices, oblique pronouns or reiteration of the subject word(s). Although both can be heard east and west of the Atlantic, one is more likely to hear the former in Portugal-Muito prazer em conhecê-lo, Delighted to meet you-and the latter in Brazil-Muito prazer em conhecer você, Delighted to meet you. The future will tell whether this coexistence will be maintained.

\section{Conclusion}

In modern Portuguese, forms of address operate within a system where there have been vital changes in relation to the original second-person system inherited from Latin and headed by subject pronouns "tu" and "vós". A key step in the process of evolution has been the establishment of a nominal-format, whereby a noun element in the subject constituent results in third-as-second person forms. This is the case of "o senhor / a senhora", a noun, and "você", a noun-based word. Another decisive factor of change has been a new orientation in mode of address. As societies become less stratified and more equalitarian, a neutral approach becomes more relevant. A good candidate to this post is "você". It derives from an old honorific which, along the centuries, has undergone successive phonetic and semantic reductions and has nowadays the potential to house the notion of a neutral form of address bypassing $\mathrm{V}$ and $\mathrm{T}$ roles. Therefore, in the assessment of Portuguese second person and forms of address, the customary V/T framework of analysis for pronouns of address is inadequate on two fronts. It does not cater for noun or noun-based subject constituents; but it is limited to pronouns. It also does not cater for a platform of neutrality (N); but it is limited to a formal (V) / informal (T) dichotomy. In this paper a more comprehensive policy of assessment has been taken. Both pronominal and nominal forms of address are taken into account, and $\mathrm{N}-\mathrm{V}-\mathrm{T}$ is the framework of analysis.

Changes are taking place on both sides of the Atlantic which can result in "você" becoming an encoder for N, in its performance comparable to English uncommitted you. Semantically, in Portugal, this word is losing the negative 
overtones it used to bear, and, in Brazil, a solution may have been found to overcome its current link to the close-relations circle. Structurally, inflection may be at the core of possible changes. Although today it can be perceived as a second-person pronoun, subject constituent "você" continues to take thirdperson verb ending, as determined by the noun component in its origin. Conjugation patterns are therefore the same as for the noun subject constituent used in the V sphere, "o senhor / a senhora". In the T sphere there is variation. In Portugal, all the elements of the tu-paradigm are in usage, including subject constituent "tu" and respective second-person verb ending. In Brazil, there is a fluid situation. At national level, preference is given to "você", which is complemented with tu-paradigm oblique pronouns and possessives, for a more familiar, matey or intimate tone. In a number of states, however, "tu" is being retained, though often taking third-person verb ending. Should this practice be accepted in Brazil as a whole and indeed become norm in the Lusophone world, then the Portuguese language would have a complete N-V-T triad sharing the same verbal inflection; and shades of meaning would be left to the subject marker. V would be conveyed by a noun subject, typically "o senhor / a senhora" and T by "tu". N would be performed by uncommitted "você" as an alternative to the current zero-subject approach.

We have seen how the Portuguese forms of address and second-person system rely chiefly on the nominal-format. Notwithstanding, elements from the former "tu-vós" model still make their presence felt, albeit with updated duties. This compromise may continue in the future. Old subject pronoun "vós" has fallen out of general use but "tu" may have withstood the test of time. One can speculatively contemplate a scenario in which the latter will assume a renewed identity and enter the nominal-format, as a $\mathrm{T}$ subject constituent on a par with "você" for N and "o senhor / a senhora" for V. Mainly out of the tu-paradigm, but to some extent also out of the vós-paradigm, forms are in currency for object pronouns and possessives. In some cases there are nominal alternatives, in an oscillation of practice that may continue or eventually give way to a single route. As one final comment on the nominal-format, mention must be made to the fact that, semantically, the noun element opens endless possibilities. This feature is of particular relevance in a language like Portuguese, which is spoken 
in different parts of the globe, inasmuch as it can attend to a wide spectrum of sociolinguistic preferences and $\mathrm{N}-\mathrm{V}-\mathrm{T}$ nuances around the Lusophone world, now and in the future.

\section{Works Cited}

Azeredo, José Carlos. Fundamentos de Gramática do Português. Rio de Janeiro: Jorge Zahar, 2000. Print.

Azevedo, Milton M. Portuguese. A Linguistic Introduction. Cambridge: Cambridge UP, 2005. Print. Azurara, Gomes Eanes de. Crónica dos Feitos da Guiné. II Texto. Lisboa: Dias Dinis, 1949. Print. Barbosa, P., M. Duarte, and M. Kato. "Null Subjects in European and Brazilian Portuguese." Journal of Portuguese Linguistics. Web. 23 Jun. 2013. <http://repositotium.sdum.uminho.pt/bitstream/>.

Barros, Vítor Fernando. Gramática da Língua Portuguesa. Lisboa: Edições Colibri, 2011. Print. Bechara, Evanildo. Moderna Gramática Portuguesa. Rio de Janeiro: Nova Fronteira, 2009. Print. Bell, Allan. "Back in Style: Reworking Audience Design." Style and Sociolinguistic Variation. Cambridge: Cambridge UP, 2001: 139-169. Print.

Borges-Cardoso, Daisy Bárbara. "Variação e mudança no português brasileiro: gênero e identidade.” Diss. U of Brasília, 2009. Print.

Brown, Penelope, and Stephen C. Levinson. Politeness. Some universals in language usage. Cambridge: Cambridge UP, 1987. Print.

Brown, Roger, and Albert Gilman. “The Pronouns of Power and Solidarity." Style in Language. Cambridge, MA: MIT Press (1960): 253-76. Print.

Clyne, Michael, Catrin Norrby and Jane Warren. Language and Human Relations. Styles of Address in Contemporary Language. Cambridge: Cambridge UP, 2009. Print.

Cook, Manuela. “On the Portuguese Forms of Address: From 'Vossa Mercê' to 'você”' Portuguese Studies Review 3.2 (1995): 78-89. Print.

. "You' the customer in the Portuguese language of advertising." International Journal of Iberian Studies 9.1 (1996): 19-27. Print.

. "Uma Teoria de Interpretação das Formas de Tratamento na Língua Portuguesa." Hispania 80.3 (1997): 451-464. Print. English version: A Theory for the Interpretation of Forms of Address in the Portuguese Language. Web. 23 Jun. 2013. <www.lusophonepublishing.com/nvt-theory.html>. . Portuguese Verbs Explained, an essential guide. Knebworth: Able, 2004. $2^{\text {nd }}$ ed. Greenhithe: Lusophone Publishing, 2009. Print.

. "Portuguese forms of address—not V/T but N-V-T." ACIS Conference. King's College, U of London. 4-6 Sep. 2012. Presentation.

Coupland, Nik. "Language, situation and the relational self: Theorizing dialect-style in Sociolinguistics." Style and Sociolinguistic Variation. Cambridge: Cambridge UP, 2000: 182210. Print. 
Crystal, David. Language and the Internet. Cambridge: Cambridge UP, 2001. Print. . English as a Global Language. Cambridge: Cambridge UP, 2003. Print.

Gonçalves, Clézio Roberto. "Uma abordagem sociolinguística dos usos das formas 'você,' 'ocề e 'cể no português.” Diss. U of São Paulo, 2008. Print.

Labov, William. Principles of Linguistic Change. Vol I, Internal Factors. Oxford: Blackwell, 1994. Print. . Principles of Linguistic Change. Vol II, Social Factors, and Vol III, Cognitive and Cultural Factors. Oxford: Blackwell, 2001. Print.

Lindley-Cintra, Luís Filipe. Sobre Formas de Tratamento na Língua Portuguesa. Ensaios. Lisboa: Livros Horizonte, 1972. Print.

Mattoso-Câmara, Joaquim, Jr. The Portuguese Language. Trans. Anthony J. Naro. Chicago UP, 1972. Print.

Moura-Neves, Maria Helena. Gramática de Usos do Português. São Paulo: UNESP, 2003. Print.

Oxford Dictionaries. Concise Oxford Dictionary. Oxford: Oxford UP, 2011. Print.

Perini, Mário A. Modern Portuguese. A Reference Grammar. New Haven: Yale UP, 2002. Print.

Pountain, Christopher J. "Pragmatic and Structural Reflections on the Expression of the Second Person Notion in Romance, with Special Reference to Spanish and Portuguese." Bulletin of Spanish Studies 80.2 (2003): 146-160. Print.

Scherre, Maria Marta Pereira et al. "Usos dos pronomes você e tu no português brasileiro." II SIMELP. U of Évora. 6-11 Oct. 2009. Presentation.

Silva-Neto, Serafim da. História da Língua Portuguesa. Rio de Janeiro: Presença, 1979. Print.

Teyssier, Paul. História da Língua Portuguesa. Trad. Celso Cunha. São Paulo: Martins Fontes, 2001. Print.

Thomé-Williams, Ana Clotilde. "Sociolinguistic aspects of forms of address in Portugal and Brazil: tu or você.” Journal of Intercultural Communication Studies XIII.3 (2004): 85-99. Print.

Tostevin, Helena, and Manuela Cook. "O senhor, você ou tu? You, you or you? (Forms of address)." 50 Ways to Improve Your Portuguese. London: Hodder, Hachette, 2010: 108-10. Print.

Vázquez-Cuesta, Pilar, and Maria Albertina Mendes da Luz. Gramática da Língua Portuguesa. Lisboa: Lexis, Edições 70, 1971. Print.

Manuela Cook has held lecturing and examining posts in Portuguese Studies at the University of Wolverhampton and the University of London, in England. She has delivered papers at several institutions in Higher Education and published articles in several academic journals, in the UK, USA, Portugal, Brazil and France. Her research interests include Linguistics, in particular Sociolinguistics, with a specific focus on pronouns and other forms of address. She is a Fellow of the Chartered Institute of Linguists. 